\title{
Effect of petroleum derivatives on some antioxidant and oxidative stress parameters in sheep in Khanaqeen city
}

\author{
Mahmood Ahmed Husse in ${ }^{1}$ Qussai Salih Jumaa ${ }^{2}$ Qassim Ibrahim Khalaf ${ }^{3}$
}

1 Department of animal production, faculty of agriculture , university of Garmian

2 Department of Pathology, faculty of veterinary medicine, university of Tikrit

3 Diy ala Directorate of general education, Iraq

\begin{abstract}
The current study was achieved to investigate for some of biochemical parameters associated with pollution of sheep with petroleum derivatives and it's effects on some parameters of oxidative stress and antioxidant. The blood samples were collected from 70 sheep and divided into two groups, the first group included 15 from other city and very far from center of pollution ( about $200 \mathrm{Klm}$ ) which consider as a control group, while the second group included 55 sheep near the center of pollution ( about $3 \mathrm{Klm}$ ) which represent affection group. The results showed that the affection group cause significant increase in oxidative stress parameters (Malondialdehyde , peroxynitrate radical $)(\mathrm{P} \leq 0.05)$. and we see from this study significant decrease in antioxidant parameters (Glutathione, glutathione peroxidase enzyme, superoxide dismutase enzyme ) in the affection group. We can concludes from this study that the Effect of petroleum derivatives impact adversely on antioxidants accompanied by an increase in the level Malondialdehyde and peroxynitrate radical which consider as indicators for oxidative stress that is a companion Effect of petroleum derivatives.
\end{abstract}

\section{Introduction}

With the development of oil industry, the general environment and in particular wet land ecosystem has become extremely vulnerable to damaging effects of oil pollution .Contamination of environment by crude oil and petroleum products constitute an additional source of stress to organisms (1) Crude petroleum is a mixture of different hydrocarbons and metals. (2) The chemical composition of crude petroleum varies between geologic formations. (3) It may be refined into fractions of kerosene, petrol, diesel, heavy gas oils, lubricating oils, as well as residual and heavy fuels among others; however, kerosene, petrol, and diesel are the most commonly used fractionated crude petroleum products. These fractions contain aliphatic, aromatic, and a variety of other branched saturated and unsaturated hydrocarbons at variable concentrations. (4,5) Do mestic and industrial use of petroleum, either in its crude or refined forms, has increased tremendously, (3) leading to increased exposure of users to its various constituent hydrocarbons. The common forms of exposure are inhalation, dermal contact, and ingestion of petroleum-contaminated food and water. Studies have documented the adverse environ mental and health effects of petroleum hydrocarbons over the years. Previous studies reported cardiotoxic (6) hepatotoxic $(7,8)$ nephrotoxic(9) and hematoxic (10) .

\section{Material and Methods}

The blood samples was collected from 70 sheep and divided into two groups, the first group include 55 sheep around the center of pollution ( about $3 \mathrm{Klm}$ from Al-nafet Khana ), the second group included 15 fro m normal sheep that breeded in the another city and very far from center of pollution (about $200 \mathrm{Klm}$ ) . the parameters which was studied include :

1- Glutathione The determination of glutathione concentration follows the method described by (11). 
2- Malondialdehyde measurement of it follows the method described by (12).

3- Peroxy nitrate radical measurement of it follows the method described by (13).

4- Superoxide Dismutase activity Determination of it follows the method described by (14).

5- Glutathione peroxidase activity Determination of it by kit that supplied from Cayman Chemical Company ( U.S.A ).

Statistical Analysis

The data were analy zed statistically by one-way ANOVA. Values in the tables indicate the Mean \pm S.D values.

Results and Discussion

Table : explain the value of parameters

\begin{tabular}{|c|c|c|}
\hline \multirow{2}{*}{$\begin{array}{l}\text { Groups } \\
\text { Parameters }\end{array}$} & \multicolumn{2}{|l|}{ Mean \pm S.D } \\
\hline & Control & Contaminated Groups \\
\hline $\begin{array}{l}\text { Glutathione } \\
(\mu \mathrm{ml} \mathrm{L})\end{array}$ & $\begin{array}{l}0.185 \pm 2.23 \\
\mathrm{a}\end{array}$ & $\begin{array}{l} \pm 0.1321 .62 \\
\mathrm{~b}\end{array}$ \\
\hline Super oxide dismutase (U/L) & $\begin{array}{l} \pm 1.20133 . \\
\mathrm{a}\end{array}$ & $\begin{array}{l}2.7 \pm 0.982 \\
b\end{array}$ \\
\hline Glutathione peroxidase $(\mathrm{mmol} / \mathrm{min} / \mathrm{ml})$ & $\begin{array}{l} \pm 0.0120 .63 \\
\mathrm{a}\end{array}$ & $\begin{array}{l} \pm 0.0620 .36 \\
\mathrm{~b}\end{array}$ \\
\hline $\begin{array}{l}\text { Malondialdehyde } \\
(\mu \mathrm{ml} L \mathrm{~L})\end{array}$ & $\begin{array}{l}5281 . \pm 92.92 \\
\mathrm{~b}\end{array}$ & $\begin{array}{l}1.901137 .32 \pm \\
\mathrm{a}\end{array}$ \\
\hline $\begin{array}{l}\text { Peroxy nitrate radical } \\
(\mu \mathrm{ml} L \mathrm{~L})\end{array}$ & $\begin{array}{l}0.001 \pm 0.06 \\
\mathrm{~b}\end{array}$ & $\begin{array}{l}0.002 \pm 0.12 \\
\mathrm{a}\end{array}$ \\
\hline
\end{tabular}

significant difference at $(\mathbf{P} \leq \mathbf{0 . 0 5})$

Values are given as mean \pm SD

Differences in the letters in the row is indicator to the difference in significant level

We are see from above schedule that the pollution with oil derivatives causes decrease significantly in the level of (glutathione, Glutathione peroxidase, Super oxide dis mutase) in the affected groups and these changes may be due to oxidative stress state that accompanied the pollution, Oxidative stress occur when the production of reactive oxygen species (ROS) overwhelms the endogenous protection afforded by antioxidant enzy mes like catalase, superoxide dismutase, glutathione S-transferase and redox sensitive thiol compound, reduced glutathione. Glutathione is the most copious non-protein thiol (15) . Reduced glutathione acts as the fundamental line of defense to cope with the destructive effects of reactive oxygen species (16) and protect cells against oxidative injury as it conjugates with compounds of exo - and endogenous origin (17). This reduction in blood GSH could represent an increased utilization due to oxidative stress which is evidence in the high level of lipid peroxidation marker (malondialdehyde) observed in the serum (18). The antioxidant enzy mes SOD, CAT, and glutathione peroxidase (GPx) serve as a primary line of defense in destroying the free radicals produced by oxidative stress. SOD reduces the radical superoxide $\left(\mathrm{O}_{2}-\right)$ to form hydrogen peroxide $\left(\mathrm{H}_{2} \mathrm{O}_{2}\right)$ and oxygen $\left(\mathrm{O}_{2}\right)$; then, CAT and GPx work simultaneously with the protein glutathione to reduce $\mathrm{H} 2 \mathrm{O} 2$ and ultimately produce water $\left(\mathrm{H}_{2} \mathrm{O}\right)$. The increased MDA level and decreased SOD, CAT, and GSH suggest that exposure to petroleum hydrocarbons caused oxidative stress by consuming the protective free radical scavengers. (19). Lipid peroxidation is one of the major mechanisms involved in oxidative cell injury and an increase in Malondialdehyde (MDA) level is frequently observed during oxidative stress and has generally been used as a marker of oxidative damage (20). It is also a major oxidation product of peroxidized polyunsaturated fatty acids and increased MDA content can be related to degradation of an environment due to poor water quality (21). The significant increase in lipid oxidation (MDA) may indicate the susceptibility of lipid molecules to reactive oxygen species and the extent of oxidative damage imposed on these molecules. We 
also see the significant increase in Peroxynitrate radical in the affected group and this is may be due to reaction between superoxide radical with Nitric Oxide and both accompanied the pollution, and Peroxynitrate radical consider toxic agent which has strong oxidative properties that effect on biological molecules ( amino acids, lipids, nucleic acids ) ultimately effects on DNA and mutagens will accrued (22).

In conclusion, this study shows that exposure to petroleum hydrocarbon is a risk factor for impairment of general health,production,fertility and quality of meat via a mechanism dependent on oxidative stress, increasing lipid peroxidation and reducing enzymatic antioxidant defense mechanis $\mathrm{m}$. We therefore suggest that caution should be taken to reduce exposure to hydrocarbons.

\section{References}

1- Omoregie, E.. (2010). Effects of water soluble fractions of oil on carbohydrate reserves of Oreochromis niloficus (L). Journal of Aquatic Science. 12:1-7.

2- Edwards, C.(2008). Toxicology of oil field waste hazards to livestock associated with the petroleum industry. Vet Clin North Am.5:363-374.

3- Coppock.(2008). Toxicology of oil field pollutants in cattle: A review. Vet Hum Toxicol.37:369-576.

4- Uboh F.(2012).Comparative nephrotoxic effect associated with exposure to diesel and gasoline vapours in rats. J Toxicol Environ Health Sci .1:68-74.

5- Aboutabl, M.(2012).Inhibition of soluble epoxide hydrolase confers cardioprotection and prevents cardiac cytochrome P450 induction by benzo (a) pyrene. J Cardiovasc Pharmacol.57:273-281.

6- Barath, S.(2012).Impaired vascular function after exposure to diesel exhaust generated at urban transient running conditions. Part Fibre Toxicol.7:19.

7- Ovuru, S.(2014).Biochemical blood parameters in semi-adult rabbits experimentally fed crude oil contaminated diets. Afr J Biotechnol .3:343-345.

8- George, M.(2011).Effect of vitamin E on biochemical parameters in albino rats treated with gasoline. J Sci Res.3:641-649

9- Orisakwe, E.(2014). Investigation into the nephrotoxicity of Nigerian bonny light crude oil in albino rats. Int J Environ Res Public Health .1:106-110

10- Adebayo, A.(2010).Toxicological evaluation of precocene II isolated from Ageratum conyzoides L. (Asteraceae) in Sprague Dawley rats. Afr J Biotechnol;9:2938-2944

11- Beutler, E.(1963). Improved Method for the determination of blood GSH J. Lab. And Clin. Med. 61(5). 882-302.

12- Gilbert, H. (1984). A method of correct for errors caused by generation of interfering compounds during erythrocyte lipid peroxidation. Analyt. Biochem. 137: 282-286.

13- Vanuffelen, B.(1998). Biochem. J. 330, 719. Cited by AL-Zamely et al., 2001. The level of malondialdehyde after activation with $\left(\mathrm{H}_{2} \mathrm{O}_{2}\right.$ and $\left.\mathrm{CuSO}_{4}\right)$ and inhibition by Desfero xamine and Molisidomine in serum of patient with acute myocardial infarction. National J. of chemistry, 139-148. 5; 2002.

14- Linder,M. (1996) . Am .J. Clin. Nutr 63: 7775-8115.

15- Ueno, Y.(2002). Dietary glutathione protects rats from diabetic nephropathy and neutropathy. J. Nutr., $900-897: 132$.

16- Bradley, A.(2010). Glutathione metabolis $m$ as a determinant of therapeutic efficiency. Cancer Res., 44: 4224-4232

17- Singhal, R.(2008).Glutathaione, a 1 st Line of defense against cadmium. toxicity. FASEB J., 1: 220 223.

18- Arise, R.(2013). Assessment of water quality parameters from swamps around Kokori-Erhoike petroleum flow station in Delta State, Nigeria. Der Chemica Sinica, 4(1): 155-161.

19- Otitoju, O.(2009) . Biomarkers of Pesticide - Contaminated Environment. Pesticides in the Modern World- Pests Control and Pesticides Exposure and Toxicity Assessment. 241-252.

20- Yildirin, N.(2010).. Evaluation of environmental pollution at Munzur River of tunceli applying oxidative stress biomarkers in capoeta trutta . J. Anim. Plant Sci., 21(1): 66-71. 
21- Charissou, A.(2012). Relationship between two oxidative stress biomarkers, malondialdehyde and 8oxo-7, 8-dihydro-2'-deoxyguanosine, in the freshwater bivalve Unio tumidus. Sci. Total Environ., 322(1-3): 109-122.

22- Janoff, A.(2011). Effects of tobacco smoke on cellu lar and biochemical processes in the lung. Am. Rev. Respir. Dis. 136, 1058-1064. 